Bogna Kędzierska, PhD

Marta Znajmiecka-Sikora, PhD

The Chair of Human Development Psychology

Institute of Psychology, Faculty of Educational Sciences

University of Lodz, 91-433 Łódź, Smugowa 10/12

Poland

\title{
PERSONAL GROWTH AND PERSONAL DEVELOPMENT - ANALYSIS OF TERMS IN THE CONTEXT OF THE LIFE-SPAN DEVELOPMENT IDEA
}

As adults, we have a measure of choice and we are able to change Selligman (1993, p. 36)

\section{Introduction}

Basic terms within the traditional concepts of developmental psychology are development and change. As changes are universally experienced, the terms of change and development are sometimes used interchangeably. Therefore, attempts at defining criteria to enable isolating changes that are of the developmental nature from among observable ones have become the principal objective of psychological theories and concepts of development.

Specialist literature offers a great number of concepts striving to find criteria that would help in distinguishing a change of the developmental character from such that is devoid of that feature. The concepts can be sorted based on how they answer two basic questions concerning development. One of those is a question about the nature of that phenomenon, the other - about the mechanism of its occurrence (compare: Trempała, 2000). From the perspective of life-span developmental psychology, while attempting to define basic terms, the following question is mainly tried to be answered: what shapes the course of human life and how is it shaped (Brzezińska \& Trempała, 2000).

H. Bee (1994) specified three types of changes of interest to developmental psychology: 
- universal changes that occur universally, concern every human being and are associated with age,

- changes common to a certain group, characterizing individuals being part of a certain structure, resulting from participating in similar situations,

- and individual changes caused by unique factors, affecting solely a given individual.

Research into the process of human development must take into account all the above-mentioned types of changes, especially when a question is asked about the determinants of development.

At present, the term of developmental change usually encompasses changes of the constant, gradual, unidirectional and irreversible nature, leading to higher complexity and integrity (compare: Krajewski, 1997, quoting: Brzezińska, 2000; Zamiara, 1988). Attention should be paid to the fact that contemporary discussions on development particularly emphasize a view of the importance of qualitative changes and the autonomic nature of development (Przetacznik-Gierowska \& Tyszkowa, 2000).

Despite a great variety of human development concepts, nowadays two traditions of developmental psychology or even two theories of psychological development are usually referred to: classical developmental psychology and life-span developmental psychology. According to the classical developmental psychology, development is a process of accumulation or/and integration of directional changes, universally arranged into a sequence of progressive transformations representing a higher and higher level of functioning and aimed at a specific final state (Brzezińska \& Trempała, 2000). Life-span developmental psychology regards development as a process taking place throughout an individual's life. The essence of development is a change in adaptive skills (most commonly understood as an ability to build relations with people around an individual), while its characteristic feature is plasticity that allows various directions of individual development depending on individual and environmental resources at a person's disposal (Trempała, 1997). As a consequence, developmental research has shifted its attention to the third type of changes in the classification by Bee (1994) and begun to focus on individual changes needed by a given individual or small group (e.g. a family) and conditions enabling those changes. Development understood in such a way has gone beyond the scope of developmental psychology as a subject of interests or analyses:

- it has become the central point for the whole research connected with the process of teaching, nowadays being considered a development stimulation process (Ledzińska, 1996),

- it has become an important term within the framework of psychological help in its broad sense, where a great number of methods aimed at development support have been worked out (compare: Kędzierska \& Znajmiecka-Sikora, 2011),

- health psychology has drawn particular attention to specific developmental experiences associated with going through traumatic situations such as, for example, a serious life-threatening disease, 
- in positive psychology relationships between personal development and subjective well-being are analysed in the scope of research on happiness.

While analysing terms that appear mainly in the area of research concerning individual changes and, in particular, changes associated with adults' personal development, it seems that specialist literature has devoted attention to two qualitatively different developmental phenomena - personal development and personal growth. Researchers attempt to compare both the phenomena with increasing frequency.

The aim of the article is to review existing concepts of and attempts at differentiation between the two terms being fundamental to life-span developmental psychology - personal development and personal growth.

\section{Personal Development and Personal Growth - Review of Positions}

A common saying based on everyday observations that "what doesn't kill you makes you stronger" has only recently become the focus of research interest among psychologists. Initially, however, a subjective feeling that, as a result of difficult experiences, someone has changed for the better ("has grown") as a person was considered a kind of strategy to cope with stress (e.g. positive re-evaluation, positive illusions - compare: Affleck \& Tennen, 1996; Taylor \& Armor, 1996, quoting: King, 2002). Yet, more and more often, literature offers a view that, in such cases, we can rather observe a specific developmental phenomenon.

Therefore, despite a certain term ambiguity, the two developmental phenomena begin to be clearly differentiated in recently presented studies. On one hand, adults' development is analysed and described in association with the process of developmental changes most frequently resulting from a more or less planned activity of an individual himself or herself. When understood in such a way, development rather consists in developing various aspects or competences. On the other hand, a developmental phenomenon is described that is connected with a very noticeable qualitative change - a kind of "a jump in quality". That qualitative change leads to an impression that a human being, as a whole, has reached a higher developmental level in the scope of self-awareness, relations with people, understanding of the world and giving meaning etc. Despite or as a result of difficult experiences, he or she has undergone a general positive change as a human being.

\section{Terminological Ambiguities}

When referring to the phenomenon of developing certain competences or aspects of an individual's functioning, English language literature most frequently uses the term of development, and thus the phenomenon is most often described as personal development or personality development. In the Polish language, 
descriptions of that phenomenon also apply the term of rozwój osobowy (personal development).

On the other hand, that particular phenomenon where a qualitative change occurs is most commonly described as personal growth (in Polish: wzrost osobowy). An experience of growth is most clearly described in health psychology with reference to descriptions of traumatic events' consequences. In English, that kind of growth is described, for instance, by terms such as:

- stress related growth,

- adversarial growth,

- posttraumatic growth.

Those terms differ slightly in their descriptions of context where the growth experience may occur:

- stress related growth - growth connected with experiencing stress,

- adversarial growth - growth associated with experiencing adversities,

- posttraumatic growth - growth resulting from facing events of the traumatic nature.

In English language literature, the term of posttraumatic growth is most unambiguously defined and very consistently used in psychological literature. It describes positive changes taking place as a result of experiencing a traumatic situation. Those changes concern self-perception, interpersonal relations and philosophy of life (Tedeschi \& Calhoun, 1996).

At present, in Polish literature, a certain inconsistency appears - when describing the same kind of experiences, a majority of authors have decided to translate growth as wzrost and use the term for that particular developmental experience, i.e. wzrost postresowy, wzrost pourazowy, wzrost potraumatyczny (compare: Andrzejewska, 2008; Ziemba, Czarnecka, Van Luijken, Wawrzyniak, 2010; Bokszczanin, 2012); some authors, however, use the term rozwój potraumatyczny or, interchangeably, the two terms (Ogińska-Bulik \& Juczyński, 2010; Izdebski \& Suprynowicz, 2010; Kawiecka-Dziembowska \& Windorbska, 2010).

Posttraumatic growth can be experienced when events in our lives force us to revise the basic assumptions about who we are, who people around us are like, what the world we live in is like. That results in a fundamental change described as a feeling of being someone else ("new"), while the history of life is divided into its "before" and "after" parts (Tedeschi \& Calhoun, 2007).

Literature most often formulates four principal conditions that allow to describe an experience of change as posttraumatic growth:

- it most clearly appears in serious crisis conditions (and not in a situation of milder stress),

- it is often accompanied by transformational changes in life (that do not result from misperception or misinterpretation of an event),

- it is experienced as a result (rather than as a mechanism of coping),

- it requires a radical change in the basic assumptions concerning one's own life. 
Apart from health psychology, literature analysing various aspects of adults' development does not offer complete terminological consistence. Some researchers interchangeably use the terms of personal growth and personal development; others differentiate between them by taking into account different dimensions.

In studies by J. Bauer and D. McAdams (2004, 2010), personal growth is analysed in the context of growth goals and comprises both a subjective component - a subjectively felt need, desire for personal development - and an objective component - the actual achievement of a higher developmental level. According to the authors, specific forms/aspects of personal growth can be isolated - intellectual and socioemotional - that can be of the intrapsychological or interpersonal nature (compare: Table 1).

Table 1. Types of growth goals

\begin{tabular}{|c|c|}
\hline Growth oriented at an individual & Growth oriented at others (social/communal) \\
\hline \multicolumn{2}{|c|}{ Goals within intellectual growth } \\
\hline $\begin{array}{l}\text { - the goal is to know oneself better, create self- } \\
\text { concepts } \\
\text { - the goal is cognitive search and extension of } \\
\text { one's knowledge }\end{array}$ & $\begin{array}{l}\text { - the goal is to know others and relations with } \\
\text { them better, create concepts about others } \\
\text { - the goal is to support others' intellectual de- } \\
\text { velopment }\end{array}$ \\
\hline \multicolumn{2}{|c|}{ Goals within psychosocial growth } \\
\hline $\begin{array}{l}\text { - deeper experience of oneself, one's activities } \\
\text { and events in life } \\
\text { - supporting and strengthening important } \\
\text { personal competences significant to an in- } \\
\text { dividual }\end{array}$ & $\begin{array}{l}\text { - deeper experience of others and relations } \\
\text { with them } \\
\text { - greater capabilities of fair and protective be- } \\
\text { haviours } \\
\text { - supporting growth of others }\end{array}$ \\
\hline
\end{tabular}

Source: Bauer J.J. \& McAdams D.P. (2010). Eudaimonic growth: narrative growth goals predict increases in ego development and subjective well-being three years later. Developmental Psychology, 4, p.761-772.

According to the above-mentioned authors personal growth and personal development are inextricably linked but personal growth results from a personal intention to change when that kind of change is important to an individual; on the other hand, personal development means every change of the developmental nature - both regarding personality and sense of well-being (in the authors' opinion, most developmental changes are probably unintentional).

\section{Personal Development and Personal Growth - Proposed Definitions}

There is a group of researchers who differentiate between phenomena of personal growth and personal development in a slightly different, very consistent manner (compare: King, 2002 Irving \& Williams, 1999, Wright et al. 
2006). To sum up their erstwhile reports, both the phenomena can be described as follows:

- both development and growth result in a change but each of the terms refers to different aspects of the change. For example, "I can develop my personal abilities, potential, competences" but I cannot make them grow - growth refers to a more general, more complex change - it concerns a person as a whole and cannot be planned;

- personal development:

- refers to more specific achievements that may be of a more temporary nature,

- requires some measurement, direct comparison - without those, based on mere self-description, it is most often difficult for an individual to determine whether development has occurred,

- is not always connected with a sense of satisfaction, happiness,

- can be planned and structuralized, one can make a decision to start the process of development, set its goals and evaluate progress,

- is a more neutral term.

- personal growth:

- is a phenomenological experience - an individual is probably able to say whether he or she has experienced growth,

- is possible to be noted only in retrospect - we can observe someone's growth - in the form of its result but we are not aware of the process itself,

- is something that becomes, comes rather than happens; one cannot decide to begin the process of growth,

- may result from any kind of development - it arises from experience and an initiated process of personality development,

- contributes to a good frame of mind, feeling of happiness,

- is a positively marked term.

The authors assume that not only traumatic events but all complex and difficult interpersonal situations may spur an individual into attaining a higher ego functioning level (King, 2002).

\section{Personal Growth - Areas of Research}

The assumption that situations difficult from the point of view of an individual may become an important developmental impulse considerably extends the area of research. For instance, Wright at al. (2006) analysed experiences of young physicians who took part in postgraduate training by working as the so called resident physicians.

Experiences of resident physicians are described in literature as especially intensive and strenuous (excessively long working hours, sleep deprivation, professional challenges, feeling of being inadequately prepared, highly demanding 
work environment) and have so far been analysed from the perspective of the risk of adverse effects: stress burden, depression or professional burnout.

In Wright's research, which assumed that difficult and intensive experiences may be positively stimulating, the subjective feeling of personal growth was analysed and factors were sought that contribute to experiencing that feeling in the studied group of physicians.

Similarly to research into posttraumatic growth, the authors of the study proposed a very precise definition of personal growth and operationalized that by creating the Personal Growth Scale.

According to the authors, personal growth encompasses:

- all processes through which an individual achieves personal awareness and/or understanding and which lead to such changes in feelings, beliefs, attitudes and self-attitudes that allow better, more effective and healthier functioning.

On the other hand, conditions that allow personal growth are:

- important experiences arousing strong feelings and emotions,

- supportive and helpful interpersonal relations,

- reflection - ability/willingness to reflect upon one's own behaviour and reactions.

\section{Importance of Differentiation Between Development and Growth - Implications for Practising Psychologists}

Such a definition of personal growth contributes also to theoretical reflection upon understanding an individual's experiences within various active group forms of psychological support (trainings, psychological workshops) and sense of psychological support in difficult situations in life. It also helps to more adequately construct programmes to support people grappling with serious difficulties in their lives.

On the other hand, differentiation between the terms of personal development and personal growth is important to psychologists applying various kinds of support, including, in particular, trainers-psychologists, as well as to the training practice itself, i.e. the structure of training, set objectives and achieved results. The lack of differentiation between those terms may cause practical and ethical problems in training work, especially if criteria determining growth (e.g. becoming a certain kind of person) overlap/mix with those defining development (e.g. developing specific skills, attitudes etc.). Training actions frequently appear to focus more on facilitating, or even, to some degree, forcing participants to become a specific type of person (referring to growth criteria) instead of employing methods that allow for developing skills and facilitating development (compare: Irving \& Williams, 1999). 


\section{Summary}

The performed review of literature justifies distinguishing between the two qualitatively different developmental processes. Observations of adults' experiences indicate that we can experience a particular type of change - often described as a feeling of being someone else - if specific conditions are met.

Strong emotions aroused not only by traumatic situations but simply by experiences that are important to us, complex interpersonal situations (King, 2002), may affect our fixed attitudes and internal patterns. If we are ready for reflection or someone supports us by stimulating and facilitating attempts at understanding our own reactions and behaviours, we are able to increase our awareness of ourselves and our experiences in a special way, hence changing our perception of ourselves and the world.

The phenomenon of personal growth has been introduced into the area of research analyses and most eagerly referred to by practising psychologists - observing and analysing the phenomenon of personal growth in individuals using various kinds of psychological help - who call for conducting research in that scope.

Isolating personal growth as a specific developmental process allows to extend the area of research. For instance, reports on seeking relationships between experiences in life, personal growth and personality development (King, 2002), a relationship between personal growth and subjective well-being (compare: Bauer \& MacAdams, 2010) as well as factors enabling personal growth (Wright et al., 2006) seem to be particularly inspiring.

The phenomenon of personal growth itself requires further theoretical and research reflection. Detailed questions need to be answered about the nature and specificity of the developmental phenomenon distinguished in such a way. The following questions proposed by Crystal L. Park (2010) may be among those to provide inspiration for further research:

- Is personal growth a uniform term/phenomenon? Or should we rather refer to various types of positive changes?

- Do positive changes occurring as a result of difficult experiences have to be permanent so that they can be called growth?

- How closely do positive changes have to be connected with some difficult experiences to be regarded as growth?

- Do people have to be aware of a positive change and experiences/events that have resulted in it so that personal growth can occur?

- Does growth caused by a single traumatic event (e.g. crime, rape) differ from that resulting from a long-lasting stress experience (e.g. chronic illness)?

- What is the dynamics of the occurrence of/changes in growth like?

- Is there any critical moment that initiates growth?

- Does that moment differ depending on the kind of difficult experience (its intensity, course in time)? 


\section{References}

Andrzejewska A. (2008). Nadzieja podstawowa a poczucie koherencji poczucie sensu życia kobiet, które $w$ dzieciństwie przeżyly II wojnę światowa. Warsaw: Unpublished master's thesis, SWPS.

Bauer J.J., McAdams D.P. (2010). Eudaimonic growth: narrative growth goals predict increases in ego development and subjective well-being three years later. Developmental Psychology, 4, p. 761-772.

Bauer J.J., McAdams D.P. (2004). Personal growth in adults' stories of life transitions. Journ. of Personality, 72, p. 573-601.

Bee H. (1994). Life-span development. New York: Harper Collins College Publishers.

Bokszczanin A. (2012). Postresowy wzrost a religijność młodzieży po doświadczeniach powodzi. Opole: Speech at the Individual - Religion - Social Relations Scientific Conference.

Brzezińska A. (2000). Spoleczna psychologia rozwoju. Warsaw: Scholar.

Brzezińska A., Trempała J. (2000). Wprowadzenie do psychologii rozwoju. In Strelau J. (Ed.), Psychologia. Tom I. Gdańsk: GWP.

Irving J.A., Williams, D.I. (1999). Personal growth and personal development: concepts clarified. British Journal of Guidance and Counselling, Volume 27, Number 4, November 1999, p. 517-526 (10).

Izdebski P., Suprynowicz M. (2010). Rozwój pourazowy a prężność. In Prentka M. (Ed.), Nauki o edukacji. Rocznik Naukowy Kujawsko-Pomorskiej Szkoły Wyższej w Bydgoszczy, 5, p. 61-69.

Znajmiecka-Sikora M., Kędzierska B. (2011). Ksztatcenie ustawiczne w kontekście rozwoju człowiekagrupowe metody wspierania rozwoju (przegląd zagadnień i podstawowych pojęć) [In:] Znajmiecka-Sikora M., Kędzierska B. [Eds.], Podstawy kształcenia ustawicznego od A do Z. Psychologiczne metody wspierania rozwoju osób dorosłych Łódź: Wydawnictwo ego.

King L. A. (2002). Personal growth and personality development: forward to the special section. Journal of Personality, 70:1, p. 1-4.

Ledzińska M. (1996). O niektórych problemach kształcenia z perspektywy psychologii poznawczej. Psychologia wychowawcza, 4, p. 24-32.

Ogińska-Bulik N., Juczyński Z. (2010). Rozwój potraumatyczny - charakterystyka i pomiar. Psychiatria, 7(4), p. 129-142.

Park, C. L. (2010). Making sense of the meaning literature: An integrative review of meaning making and its effects on adjustment to stressful life events. Psychological Bulletin, 136, p. 257-301.

Przetacznik-Gierowska M., Tyszkowa M. (2000). Psychologia rozwoju człowieka. Warsaw: PWN.

Seligman E.P. (1993). Optymizmu można się nauczyć. Media Rodzina, p. 36.

Tedeschi R.G., Calhoun L.G. (2007). Podejście kliniczne do wzrostu po doświadczeniach traumatycznych. In Lindley P.A., Joseph S. (Eds.), Psychologia pozytywna w praktyce. Wydawnictwo Naukowe PWN, p. 230-248.

Tedeschi R.G., Calhoun L.G. (1996). The posttraumatic growth inventory: Measuring the positive legacy of trauma. Journ. Trauma Stress, 9, p. 455-471.

Trempała J. (2000). Koncepcje rozwoju człowieka. [In:] Strelau J. (Ed.), Psychologia. Tom 1. Gdańsk: GWP.

Trempała J. (1997). Koncepcje rozwoju psychicznego - wiele czy jedna psychologia rozwoju? Forum Psychologiczne, 2, p. 3-21.

Wright S.M., Levine R.B., Beasley B., Haidet P., Gress T.W., Caccamese S., Brady D., Marwaha A., Kern D.E. (2006). Personal growth and its correlates during residency training. Medical Education, 40, p. $737-745$.

Zamiara K. (1988). Formalne cechy rozwoju w różnych ujęciach modelowych. [In:] Tyszkowa M. (Ed.), Rozwój psychiczny człowieka w ciagu życia. Zagadnienia teoretyczne i metodologiczne. Warsaw: PWN, p. 21-43.

Zięba M., Czarnecka-van Lujiken J., Wawrzyniak M. (2010). Nadzieja podstawowa i wzrost potraumatyczny. Studia Psychologiczne, 49, p. 109-121. 